and linon mation

\title{
Warfare
}

\section{Implications for Military Operations}

David J. Gruber, Lt Colonel, USAF

July 2000

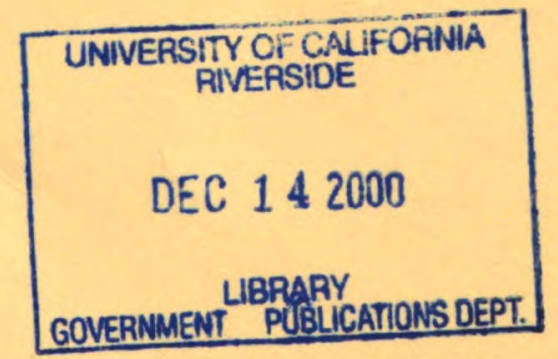

17

Occasional Paper No.17

Center for Strategy and Technology

Air War College

Air University

Maxwell Air Force Base 